of a narcotic with a lipo protein complex, appears to overcome the disadvantage of the older theories, but in its present state of development is too general and vague to be of much practical utility.

Papers dealing with the more practical side of artificial membranes were presented by Prof.
Manegold and Dr. W. J. Elford. Dr. G. S. Adair gave a paper dealing with refinements of the Donnan membrane equilibrium.

The meeting was one full of interesting topics, but somewhat discursive owing to the attempt to deal with too many diverse phenomena at one time. Eric K. Rideal.

\title{
The Soviet Expedition to the North Pole
}

$\mathrm{T}$ HE institution of a station for scientific research within a few miles of the North Pole marks a new phase in polar exploration, and is a development of the intensive exploration which the Soviet Union has pursued in Arctic regions during the last few years. The earliest attempts to penetrate high northern latitudes, away back in the sixteenth and early seventeenth centuries, were inspired by the hope of direct trade routes with the Far East and were alternatives to the still older attempts to find the NorthWest and North-East Passages. The early nineteenth century saw a revival of the northern ventures, and the Franklin disaster in the middle of that century led to a focusing of interest in polar regions, and stimulated journeys that were more adventurous than scientific in their outlook. But in an age of exploration that relied on man-hauled sledges and preserved food, that feared low temperatures and had to reckon with inevitable scurvy, the inner polar regions maintained their isolation.

Petermann's hypothesis of an open polar sea led to more than one failure and was utterly refuted by Nares, Greely and others. Then Nansen, imbued with scientific aims, brought a new technique to bear on the problem. The pack-ice that had thwarted his predecessors was to afford him the means of advance, and so in the drifting Fram he penetrated to lat. $86^{\circ} \mathrm{N}$., and on foot some miles farther north. Nansen discovered a deep, landless polar ocean covered with drifting pack-ice. There the solution of the polar problem was to rest for some years. Even if Cagni beat Nansen's record by a few miles and Peary actually reached the Pole in 1909, these expeditions were mainly adventurous achievements and added little to scientific research. Amundsen's attempt to emulate Nansen had its value but failed to gain a high latitude.

Sledge and ship had both played their part in different ages : air-voyaging was next to be tried. Early attempts were naturally failures. In 1925 Amundsen reached $87^{\circ} 43^{\prime} \mathrm{N}$. by air and returned with difficulty. In 1926, with Nobile, he crossed the Pole by airship, and in the same year Byrd also reached the Pole. These attempts showed not only the possibility of flying in arctic regions but also revealed large smooth floes with a relative lack of pressure ridges in the vicinity of the Pole. None of these expeditions, however, stayed more than a few hours, and others much less, at the Pole or anywhere in inner polar regions. Thus observations were casual and of little help, while little or no oceanographical work could be done.

Prof. O.J. Schmidt, who is in charge of the Soviet expedition to the Pole, aims at a more valuable type of exploration in placing a party in the vicinity of the North Pole for at least twelve months. The experience of arctic flying and arctic conditions generally that Soviet aviators and explorers have gained in recent years makes this possible. In connexion with the northern sea route between Europe and the Siberian rivers, of which much use is now being made, meteorological observations from the far north will be invaluable, especially in relation to the movements of the pack-ice. These observations are to be taken both at sea-level and at high altitudes. The direction of the ice drift will be studied and Prof. Schmidt points out that the station will be shifting continually in position, but it is not known if this shift will be steadily in one direction or rotatory around a certain point. In any event, these movements will facilitate soundings of the depths of the Arctic Ocean, of which little is known.

Chemical and physical analyses of the water are important in relation to the inflow of Atlantic water, and the bearing of that inflow on ice formation and ice-wastage. Good and bad ice years have long been recognized at Spitsbergen, Greenland and in the Kara Sea, but the factors involved are not understood and prediction is impossible. Magnetic and geophysical researches are also planned and biological examinations of the seawater will be made. The station will be in radio communication with Moscow, and, it is hoped, in flying communication through many months of the year. The smooth floes afford a suitable 
aerodrome, and shelters are being constructed. The Soviet Union Year Book Press Service, to which we are indebted for information, lays stress on the importance of the researches in establishing regular communication by air between Europe and America across the Arctic Ocean, a modern revival in new guise of the earliest dream of a transpolar route.

Prof. Schmidt has chosen as the resident leader of the station I. D. Papanin, who has had long experience in Franz Josef Land and at Cape Chelyuskin. With him are three other experienced men, E. T. Krenkel, P. P. Shirshov and E. K. Federov. The winter dwelling is to be a tent of duralumin and rubber lined with eiderdown, reindeer hide and canvas. It is $3.7 \mathrm{~m}$. long, $2 \cdot 7 \mathrm{~m}$. wide and $2 \mathrm{~m}$. high, and has windows of unbreakable glass. The whole tent weighs only $350 \mathrm{lb}$. This will replace the silk hut used on the expedition's arrival on May 21. Paraffin is to be used for cooking and for generating electric light. The original site of the station was 20 kilometres from the North Pole on the Franz Josef Land side.
R. N. R. B.

\section{Obituary Notices}

\section{Prof. Alfred Adler}

A LFRED ADLER, who died suddenly on May 28, was the son of a Viennese merchant. He was born in 1870 and educated in Vienna. He decided to study medicine and qualified at the age of twentyfive years. Soon after qualification he fell under the influence of Freud, and formed one of that close little group which developed the new science of psychoanalysis. He stood some of the almost universal abuse which was flung against the Psychoanalytical Society when the new ideas became known.

In spite of this, Adler's ideas never accorded closely with those of Freud and almost from the beginning he showed that he intended to take a different road from his master. Whereas Freud developed elaborate psychic entities based upon the unconscious-the id, the superego and so on-Adler tended to simplify instead of elaborate.

So early as 1907 Adler described the influence of what he called 'organ inferiority'. He described cases which showed that the inferiority of an organ or group of organs might occur as a tendency in one individual or even in a family. He noticed that one person might have a series of diseases all attacking, for example, the urinary system. In the case of a family, one member after another would suffer from diseases all centred on one organ.

From this idea of the inferiority of an organ or group of organs, Adler developed the theory of "overcompensation'. He felt that not only did the body try to compensate itself for the weakness but even succeeded in fortifying itself to an unnecessary degree, as, for example, when the scar following a wound is thicker and stronger than the original skin. $\mathrm{He}$ believed that this 'overcompensation' was not limited to the somatic or body-structure but also invaded the psychic superstructure. The result of this was that the organ which started as inferior was finally so overcompensated that it became superior to the other organs. He gave Beethoven as an example of this process, his early deafness only increasing the capacity to compose more and more magnificent music.
Adler found that he could explain every phenomena by his principles of inferiority and over-compensation. $\mathrm{He}$ put forward his views openly, and as they did not accord with those of infantile sexuality which Freud was developing at this time, there was a feeling of tension in the Vienna group of the newly formed Psychoanalytical Society. Adler was therefore asked to read a paper in which he could put his ideas before the Society. The result was a tremendous storm and, in spite of the fact that he was president of the Vienna Group, he was asked to withdraw. He did so and took nine other members with him. He then founded the Society for Individual Psychology (first called the Society for Free Analysis).

Away from the trammels of the Freudians, Adler developed better and applied his views to all types of neurosis. He thought that all neurotic illness was caused by a feeling of inferiority and a wish to dominate the environment through illness. This feeling of inferiority was engendered in childhood by the infant's weakness and its relation to its parents and brothers and sisters. This view is, of course, in direct contradiction to that of Freud, who believes that neurosis is the result of maldevelopment of the sexual instinct, which produces fixations at various psychic levels.

Adler felt that since man has the greatest strength, women must have a desire to be masculine and that neurotic illness in them is to be attributed to their wish to possess the strength of a man. He called this the 'masculine protest'. He believed that this was the cause of prostitution, homosexuality and even crime, as well as neurosis. Much of the neurotic illness in men, he thought, was due to the feeling of inadequate masculinity. All symptoms were explicable as symbolic attempts to express a purpose-in fact all neurosis was the expression of a purpose; fear of falling, for example, was explained as a fear of 'falling' sexually. Vomiting was a desire to reject some unpleasant thought or fact, and so on. He called this symbolization 'organ ja:gon'.

Adler's psychology is explanatory and easy to understand, but it lacks a coherent systematization 